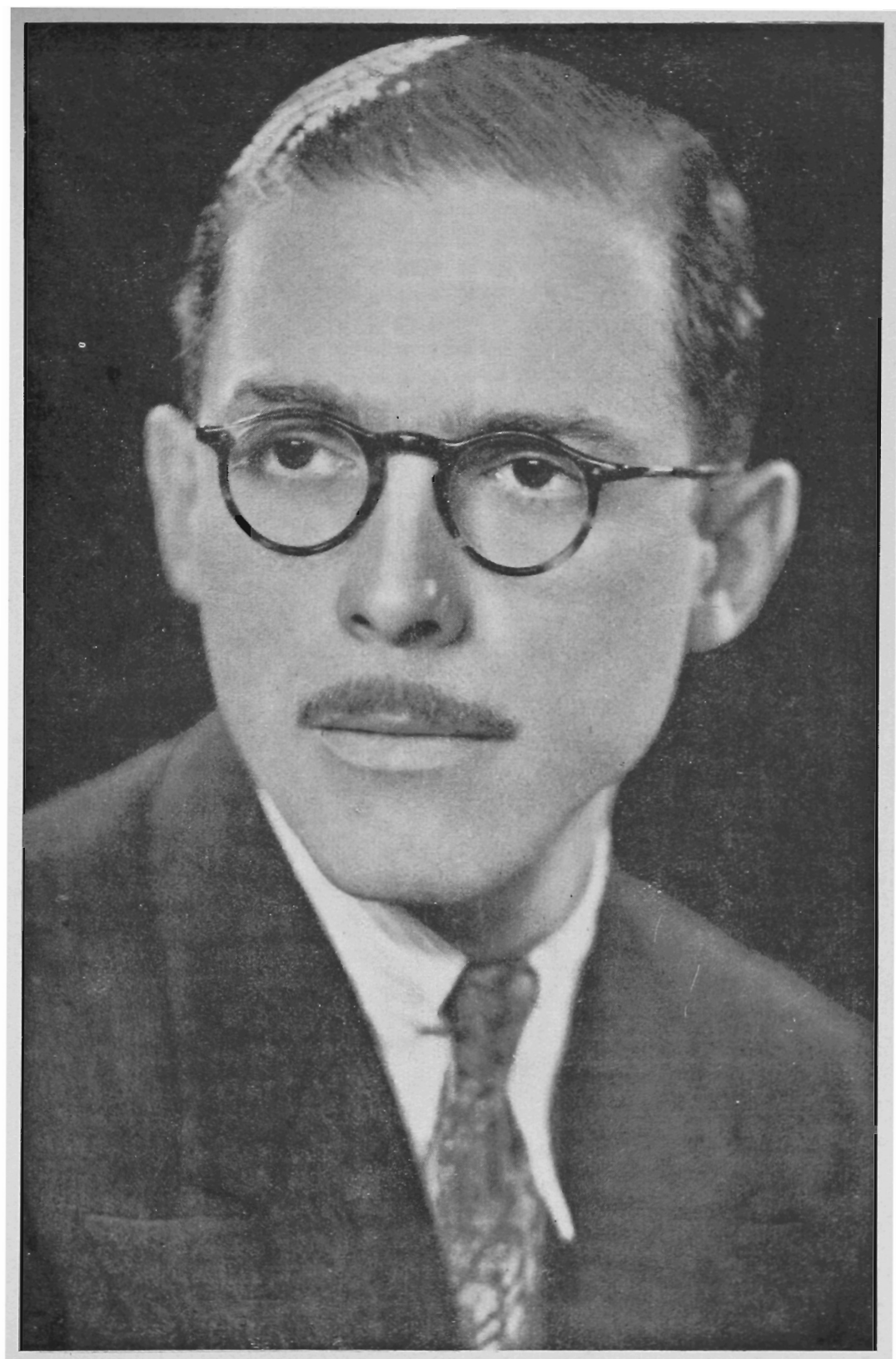

PROFESSOR JOAQUIM CANUTO MENDES DE ALMEIDA 


\section{Joaquim Canuto Mendes de Almeida}

Professor Catedrático de Direito Judiciário Penal

O novo catedrático de direito judiciário penal nasceu nesta capital a 28 de abril de 1906, filho do dr. Angelo Mendes de Almeida e de dona Jesuina de Figueiredo Mendes de Almeida. Pertence a uma família de juristas do vulto de João Mendes de Almeida, seu avô, Candido Mendes de Almeida, João Mendes de Almeida Júnior, Francisco Pennaforte Mendes de Almeida, Fernando Mendes de Almeida e Candido Mendes de Almeida Júnior, quasi todos autoridades incontestes no direito judiciário penal pátrio.

O professor Joaquim Canuto Mendes de Almeida fez os seus primeiros estudos no Ginásio de Nossa Senhora do Carmo, concluindo-os no Externato Alfredo Paulino. Ingressou na Faculdade de Direito e pertenceu à turma de 1925-1929. Foi nomeado, em 1930, promotor público de Capão Bonito; em agosto desse ano foi promovido para a comarca de Tatuí; e, em 1932, para a terceira promotoria da capital. Exerceu, como suplente, as funções de membro da Comissão Revisora do Funcionalismo Público Estadoal e representou, em 1936, o ministério público do Estado no Conselho Penitenciário de São Paulo.

Fez, em 1937, concurso para a livre docência de direito judiciário penal e, aprovado, recebeu o grau de doutor e foi nomeado em dezembro.

Em 1938, posto em comissão, como advogado, no Consultório Jurídico do Departamento de Assistência Social.

Em 1939, submeteu-se a novo concurso de direito judiciário penal e, sendo aprovado e classificado em primeiro logar, foi nomeado professor catedrático. Tomou posse em 20 de julho, em sessão solene da Congregação. 


\section{OBRAS PUBLICADAS}

1 - "Cinema contra cinema" - São Paulo - 1931 - Menção honrosa da Academia Brasileira de Letras, série de "Educação".

2 - “A contráriedade na instrução criminal" These de concurso - São Paulo - 1937.

3 - "Ação penal - Análises e confrontos" - These de concurso - São Paulo - 1939.

Por ocasião da cerimônia de sua posse, o professor Joaquim Canuto Mendes de Almeida foi saudado, em nome da Congregação, pelo professor José Soares de Mello, cujo discurso não foi taquigrafado.

Agradecendo, o novo catedrático pronunciou a seguinte oração:

"Sumamente grato pelas generosas palavras de simpatia com que me acolheis, quero, igualmente, saudar-vos, meus eminentes professores, que dora avante haveis de ser, sobretudo, meus bons amigos e companheiros de trabalho. Essas palavras acolhedoras procurarei merecê-las. Irmanarme-ei convosco na vossa árdua tarefa cultural, tomando-vos como modêlo na orientação do ensino, no respeito à disciplina e, principalmente, no zêlo carinhoso pelo prestígio da nossa velha Faculdade de Direito. Outros provavelmente, mais ilustrados pelo nome, pela inteligência e pelo saber poderiam estar hoje em meu lugar, recebendo as vossas homenagens, com maior alegria para vós, e experimentando a alegria que sinto, para maior honra desta corporação de professores. Ninguem, entretanto, encontrarieis mais devotado do que eu para reviver aqueles carinhosos sentimentos de paternal amor pela Faculdade de Direito de São Paulo que morreram quando emudeceu, na cátedra que ele tanto amava, a palavra do mestre meu predecessor. Rafael de Correi Sampáio era um afeiçoado a esta casa, cujas prerrogativas, merecidas 
num intenso labor patriótico de mais de um século, defendeu sempre com paixão. Quanto a mim, cresci na veneração de nomes cujo prestígio intelectual e moral se enrijou nos ambientes circunspectos de nossas vetustas arcadas ou cujos feitos foram frutos da seiva aqui nutrida; estudante de direito, minhas principais aspirações acadêmicas eu as dediquei à celebração, com suntuosidade, das glórias de um século de vida dos cursos jurídicos de São Paulo e Olinda e a reacender, no coração da mocidade, sentimentos de solidariedade universitária e de indefectivel amor pelo Brasil, para maior lustro nacional do nome da Faculdade de Direito; bacharel, tive sempre, mesmo de longe, os olhos e o coração voltados para este nascedouro de forças de renovação do direito no culto à Justiça e à Patria, a que quiz dar e a que vou dar, decisivamente, minha total contribuição de homem e de brasileiro; professor catedrático de Direito Judiciário -Penal, procurarei, pois, seguir essa mesma trilha, sendo para vós, para os alunos, para a Faculdade de Direito, aquilo que Rafael Sampáio sempre foi: o maior amigo." 